\title{
The effect of rye, probiotics and nisine on faecal flora and histology of the small intestine of chicks
}

\section{Maria Rakowska ${ }^{1}$, Barbara Rek-Ciepły ${ }^{1}$, A. Sot ${ }^{1}$, Ewa Lipińska ${ }^{2}$, T. Kubiński ${ }^{3}$, Irena Barcz ${ }^{3}$ and Barbara Afanasjew ${ }^{2}$}

1 Institute of Plant Breeding and Acclimatization, Radzików', 85-870 Blonie. Poland

2 Dairy Industry Institute, Parkowa 1, 00-759 Warszawa, Poland

3 Veterinary Hygiene Laboratory, Lechicka 21, 02-156 Warszawa, Poland

(Received 7 October 1992; accepted 23 February 1993)

\begin{abstract}
Feeding a diet containing $80 \%$ rye grain with a very high $(7 \%)$ content of soluble dietary fibre to broiler chicks aged from 4 to 25 days resulted in severe damage of intestinal villi and the mucous membranes of the duodenum and small intestine. Similar changes were also observed in chicks recciving the ryc dict with an addition of probiotics containing lactic acid bacteria.

The addition of the antibiotic nisine at a rate of $2 \mathrm{~g} / \mathrm{kg}$ of the rye diet protected the intestinal villi. Nisine caused increase of feed intake and body weight gain without improving feed utilization.

The rye diets, both with and without probiotics and nisine, did not induce changes in the amount and types of coliform, anaerobic or Gram $(+)$ and Gram $(-)$ bacteria in the facces of chicks after 10 and 21 days of feeding as compared with initial level.
\end{abstract}

KEY WORDS: rye, chicks, small intestine, probiotics, nisine

\section{INTRODUCTION}

Many authors have demonstrated the unfavourable effects of including rye grain in chick diets (Koreleski and Ryś, 1985; Rakowska et al., 1992a, b; Peterson and Aman, 1986). Feed intake, feed conversion and body weight gain of chicks fed diets containing more than $15 \%$ of rye is reduced. Chicks excrete yellow-brown colored, watery and sticky faeces which dry around the cloaca and adhere to the chicks feathers, legs and a floor. The reason of such effect of rye on chicks may be its greater content of poorly digested polysaccharide-protein complexes as compared with other cereals. These complexes, which are highly viscous in aqueous solution, make up the soluble fraction of dietary rye fibre.

Wagner and Thomas (1978) have shown that rye, similarly as pectins, 
stimulates the multiplication of microorganisms, mainly from the Clostridium spp., in the digestive tract of chicks and that this can be prevented by including penicillin into the diet.

The purpose of this experiment was to examine the effect of rye fed with or without the supplement of probiotics containing different proportions of lactic acid bacteria, and the antibiotic nisine, on body weight gain, feed utilization, histology of the small intestine and faecal bacterial flora in chicks.

\section{MATERIAL AND METHODS}

The study was carried out using the rye line 2256 developed at the Institute of Plant Breeding and Acclimatization by Dr L. Madej. This line is characterized by a $14.6 \%$ protein content and a high content of soluble dietary fibre $(7 \%)$.

Seventy broiler cockerels, divided into 7 groups of 10 birds each, were used in the experiment. One day-old chicks were fed a balanced control diet for four days. This diet provided $20 \%$ crude protein and $11.5 \mathrm{MJ} \mathrm{ME} / \mathrm{kg}$ and contained (in $\mathrm{g} / \mathrm{kg}$ ): maize 300 , wheat 295 , wheat bran 150 , high-protein concentrate (soya bean oil meal, meat meal, vitamins and minerals) 250 , limestone 5 . On the second day of life the chicks were placed in heated individual cages fitted with faecal collection trays and feeders which prevented spillage of feed. The chicks were weighed after 2 days and those weighing from 70 to $80 \mathrm{~g}$ were divided into groups with the mean body weight $75 \pm 0.5 \mathrm{~g}$. The experimental groups were fed a rye diet developed formerly to compare new lines of rye. The diet provided $16 \%$ crude protein and $11 \mathrm{MJ} \mathrm{ME} / \mathrm{kg}$, and contained (in $\mathrm{g} / \mathrm{kg}$ ): rye 800 , casein 50 , wheat gluten 70 , soya bean oil 30 , mineral-vitamin mixture 50 . The experimental groups were given the following diets:

I - rye diet, non supplemented

II - rye diet with $2 \mathrm{~g}$ probiotic $\mathrm{P}_{1} / \mathrm{kg}$

III - rye diet with $2 \mathrm{~g}$ probiotic $\mathrm{P}_{2} / \mathrm{kg}$

IV - rye diet with $2 \mathrm{~g}$ nisine (Applis and Baret, England) with an activity of $10^{6} \mathrm{IU} / \mathrm{g}$

$\mathrm{V}$ - control, non supplemented

VI - control, with $2 \mathrm{~g}$ probiotic $\mathbf{P} / \mathrm{kg}$

VII - control, with $2 \mathrm{~g}$ probiotic $\mathrm{P}_{2}^{\mathrm{l}} / \mathrm{kg}$.

Both probiotic were obtained from the Bioveterinary Products Plant at Drwalewo and contained freeze-dried bacteria at concentrations of $10^{\circ}$ in the following proportions: Str. faecium, Lactobacillus acidophilus, Bifidobacterium 1:1:1 $-\mathbf{P}_{1}$; Str. faecium, L. acidophilus, Bifidobacterium $2: 1: 1-\mathbf{P}_{2}$.

The chicks were fed to appetite and weighed twice weekly. Feed intake and feed utilization were calculated after 10 and 21 days of the experiment.

Bacteriological assay - Fresh faecal samples were taken from three randomly 
chosen birds in each group at the start and on days 10 and 21 of the experiment. The number of $E$. coli rods and other coliform bacteria was determined in $1 \mathrm{~g}$ of faeces which had been inoculated on the McConkey medium. The plates were incubated for 24 h at $37^{\circ} \mathrm{C}$ and the $E$. coli colonies were counted. The number of anaerobic bacteria capable of reducing sulphites was determined in $1 \mathrm{~g}$ of faeces using the Wilson-Blair medium. The number of dark colored colonies was counted after $48 \mathrm{~h}$ of incubation at $37^{\circ} \mathrm{C}$ in anaerobic conditions in an atmosphere of $\mathrm{CO}$.

The presence of Salomonella gen. in faecal samples pooled from each group was determined, using selective liquid media that is Kaufman and SF (sodium selenite). Transfers to solid media, McConkey and BG (with brilliant green) were caried out after $24 \mathrm{~h}$ incubation.

The relative proportions of Gram (+) and Gram (-) bacteria were determined in diluted faecal samples twice for each group.

Histological examination - Three randomly chosen chicks from each group were decapitated after 21 days of the experiment. Immediately after the slaughter, samples of the duodenum and more distal parts of the small intestine were taken for microscopic examination. Tissue samples were rinsed in physiological saline, fixed in ethanol, and embedded in paraffine. The 5-8 $\mu \mathrm{m}$ thick sections were stained with haematoxylin and eosine.

The results were subjected to statistical analysis using variance analysis and Duncan's multiple range test.

\section{RESULTS}

The probiotics $\mathrm{P}_{1}$ and $\mathrm{P}_{2}$ did not have a beneficial effect on body weight gain or feed utilization in chicks fed the control diet (Table 1). In chicks fed on the rye

TABLE 1 Body weight gain (BWG), feed intake and feed conversion ratio (FCR) of experimental chicks

\begin{tabular}{|c|c|c|c|c|c|c|c|}
\hline & \multirow{2}{*}{$\begin{array}{c}\text { Initial } \\
\mathrm{BW} \\
\mathrm{g}\end{array}$} & \multicolumn{3}{|c|}{10 days } & \multicolumn{3}{|c|}{21 days } \\
\hline & & $\begin{array}{l}\text { BWG, } \\
\mathrm{g}\end{array}$ & $\begin{array}{c}\text { Feed } \\
\text { intake, } g\end{array}$ & $\begin{array}{c}\text { FCR } \\
\mathrm{g} \mathrm{feed/g} \mathrm{BWG}\end{array}$ & $\begin{array}{l}\text { BWG, } \\
\mathrm{g}\end{array}$ & $\begin{array}{c}\text { Feed } \\
\text { intake, } g\end{array}$ & $\begin{array}{c}\text { FCR } \\
\text { g feedig BGW }\end{array}$ \\
\hline I-Rye unsupplemented & 75.2 & $81.9^{b}$ & $210.4^{\mathrm{c}}$ & $2.57^{b}$ & $267.0^{\mathrm{bc}}$ & $750^{\mathrm{b}}$ & $2.81^{\mathrm{b}}$ \\
\hline $\mathrm{II}-$ Rye $+\mathrm{P}_{\mathrm{I}}$ & 75.2 & $81.9^{b}$ & $213.1^{\mathrm{c}}$ & $2.60^{b}$ & $237.5^{\mathrm{c}}$ & $750^{\mathrm{b}}$ & $3.16^{\mathrm{b}}$ \\
\hline IIl - Rye $+\mathbf{P}_{2}$ & 74.9 & $92.6^{b}$ & $241.6^{\mathrm{b}}$ & $2.61^{b}$ & $241.7^{\circ}$ & $786^{\mathrm{b}}$ & $3.25^{\mathrm{c}}$ \\
\hline $\begin{array}{l}\text { IV - Rye + nisine } \\
\text { V - Control }\end{array}$ & 75.1 & $87.2^{b}$ & $252.8^{b}$ & $2.90^{\mathrm{c}}$ & $283.0^{\mathrm{b}}$ & $966^{\mathrm{c}}$ & $3.41^{\mathrm{c}}$ \\
\hline unsupplemented & 75.1 & $209.6^{\mathrm{a}}$ & $333.8^{\mathrm{a}}$ & $1.59^{\mathrm{a}}$ & $605.0^{3}$ & $1231^{\mathrm{a}}$ & $2.03^{\mathrm{a}}$ \\
\hline $\mathrm{VI}$ - Control $+\mathrm{P}_{1}$ & 75.3 & $202.7^{a}$ & $327.0^{\mathrm{a}}$ & $1.61^{\mathrm{a}}$ & $597.2^{\mathrm{a}}$ & $1225^{a}$ & $2.05^{\mathrm{a}}$ \\
\hline VII - Control $+\mathrm{P}_{2}$ & 75.2 & $201.3^{3}$ & $336.9^{\mathrm{a}}$ & $1.67^{a}$ & $602.8^{\mathrm{a}}$ & $1265^{\mathrm{a}}$ & $2.10^{\mathrm{a}}$ \\
\hline
\end{tabular}

$\mathrm{a}, \mathrm{b}-$ - means with the same superscripts within a column are not significantly different by Duncan's multiple range test $(P \leqslant 0.05)$ 
TABLE 2

The number of coliform bacteria and the proportions of Gram (-) and Gram (+) bacteria in the faeces of 3 randomly chosen chicks from each group

\begin{tabular}{|c|c|c|c|}
\hline \multirow{2}{*}{ Group } & \multicolumn{2}{|c|}{$\begin{array}{c}\text { Number of } E \text {. coli and coliform } \\
\text { bacteria/lg of faeces }\end{array}$} & \multirow{2}{*}{$\begin{array}{c}\text { Proportions of } \\
\text { Gram }(-) \text { : Gram }(+) \\
\text { bacteria } \\
\text { at } 21 \text { day of experimen }\end{array}$} \\
\hline & $\begin{array}{l}\text { expe } \\
\text { at the beginning }\end{array}$ & at 21 day & \\
\hline I & $\begin{array}{l}7.5 \times 10^{5} \\
1.5 \times 10^{8} \\
1.5 \times 10^{8}\end{array}$ & $\begin{array}{lll}7.8 & \times 10^{7} \\
4.0 & \times 10^{8} \\
3.52 & \times 10^{8}\end{array}$ & $\begin{array}{l}\text { dominance } \mathrm{G}(+) \\
\mathrm{G}(+)=\mathrm{G}(-) \\
\mathrm{G}(+)=\mathrm{G}(-)\end{array}$ \\
\hline II & $\begin{array}{l}8.7 \times 10^{\mathrm{H}} \\
1.1 \times 10^{9} \\
6.2 \times 10^{9}\end{array}$ & $\begin{array}{l}9.2 \times 10^{7} \\
3.64 \times 10^{8} \\
8.5 \times 10^{?}\end{array}$ & $\begin{array}{l}\text { dominance } G(+) \\
\text { dominance } G(+) \\
G(+)=G(-)\end{array}$ \\
\hline III & $\begin{array}{c}\mathrm{X}^{1} \\
\mathrm{X} \\
2.2 \times 10^{7}\end{array}$ & $\begin{array}{lll}4.8 & \times 10^{8} \\
6.5 & \times 10^{7} \\
5.5 & \times 10^{7}\end{array}$ & $\begin{array}{l}\mathrm{G}(+)=\mathrm{G}(-) \\
\text { dominance } \mathrm{G}(-) \\
\text { dominance } \mathrm{G}(+)\end{array}$ \\
\hline IV & $\begin{array}{l}2.4 \times 10^{9} \\
1.0 \times 10^{9} \\
1.2 \times 10^{7}\end{array}$ & $\begin{array}{lll}3.6 \times 10^{8} \\
3.36 \times 10^{8} \\
4.48 \times 10^{8}\end{array}$ & $\begin{array}{l}\text { dominance } G(+) \\
\text { dominance } G(+) \\
\text { dominance } G(+)\end{array}$ \\
\hline V & $\begin{array}{l}2.7 \times 10^{6} \\
6.7 \times 10^{9} \\
2.4 \times 10^{7}\end{array}$ & $\begin{array}{l}6.8 \times 10^{8} \\
3.25 \times 10^{9} \\
1.95 \times 10^{8}\end{array}$ & $\begin{array}{l}\text { dominance } G(-) \\
\text { dominance } G(-) \\
\text { dominance } G(-)\end{array}$ \\
\hline VI & $\begin{array}{l}X \\
X \\
X\end{array}$ & $\begin{array}{ll}2.8 \times 10^{7} \\
3.68 \times 10^{9} \\
5.8 \times 10^{8}\end{array}$ & $\begin{array}{l}\text { dominance } G(-) \\
\text { dominance } G(-) \\
\text { dominance } G(-)\end{array}$ \\
\hline VII & $\begin{array}{l}5.2 \times 10^{9} \\
\mathrm{X} \\
\mathrm{X}\end{array}$ & $\begin{array}{l}2.0 \times 10^{9} \\
1.0 \times 10^{9} \\
3.16 \times 10^{9}\end{array}$ & $\begin{array}{l}\text { dominance } \mathrm{G}(-) \\
\text { dominance } \mathrm{G}(-) \\
\text { dominance } \mathrm{G}(-)\end{array}$ \\
\hline
\end{tabular}

no results

diet, the addition of probiotic $\mathrm{P}_{2}$ resulted in a slight increase of feed intake and body weight gain during first 10 days, but after 3 weeks both feed intake and weight gain were similar as in chicks fed the rye diet without additives.

The inclusion of nisine into the rye diet significantly improved feed intake over the 21 days of the experiment, however, this was not accompanied by a proportional increase of body weight, which resulted in worse feed utilization.

The faeces of all chicks fed rye diets were watery and sticky. The addition of probiotics or nisine did not affect the condition of the faeces.

Salmonella was not found in the faeces of any chicks. The type of diet (rye or control) or feed additives (probiotics $P_{1}$ and $P_{2}$ or nisine) did not affect the faecal bacteria count significantly. The number of E. coli and coliforms at the beginning 
of the experiment ranged from $7.5 \times 10^{5}$ to $6.7 \times 10^{9}$, while after 21 days from 2.8 $\times 10^{7}$ to $3.68 \times 10^{9}$, with the differences within a group sometimes being greater than between groups (Table 2).

Anaerobic bacteria were found in 5 samples of faeces at the beginning of the experiment, their number, however, was not great and ranged from $5.2 \times 10^{2}$ to $1.4 \times 10^{3}$. In samples taken on day 10 , anaerobic bacteria were found in the faeces of only two groups (I and VI) while none were found in any sample taken after 21 days.

Gram (-) bacteria dominated in all faecal samples taken at the beginning of the experiment. The proportion of Gram (-) to Gram (+) bacteria was 70:30. Rods dominated among the Gram ( - ) forms, while rods and cocci were most common among the Gram $(+)$ bacteria and occurred in various proportions while the sporulating rods were found in lesser amounts. In the samples of faeces taken after 21 days from chicks fed on rye diets, the number of Gram $(+)$ bacteria exceeded or equalled the number of Gram (-), only in the faeces of chicks fed the rye diet with nisine Gram $(+)$ bacteria were dominating. Gram $(-)$ bacteria dominated in the faeces of all chicks fed on the control diets.

Histological examination revealed partial destruction of intestinal villi in the duodenum and their almost complete destruction in the distal segment of the

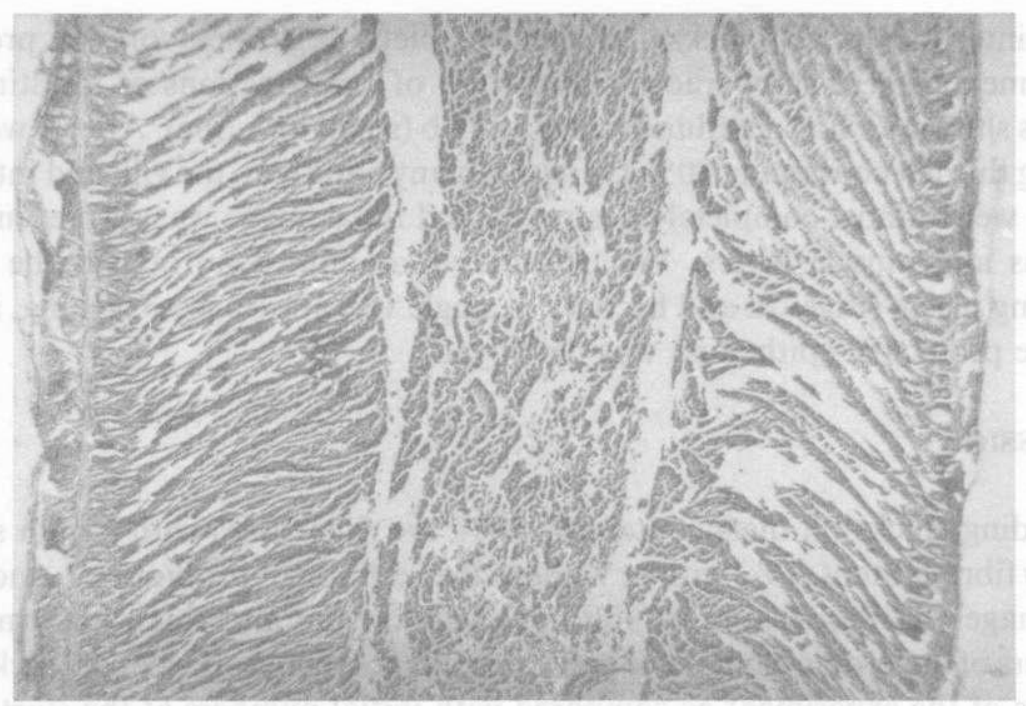

Fig. 1a. A cross - section of the duodenum wall after 3 weeks of feeding a rye diet with no additives: completely destroyed villi and intestial glands. The damage reaches the mucous membrane and muscle layer. 


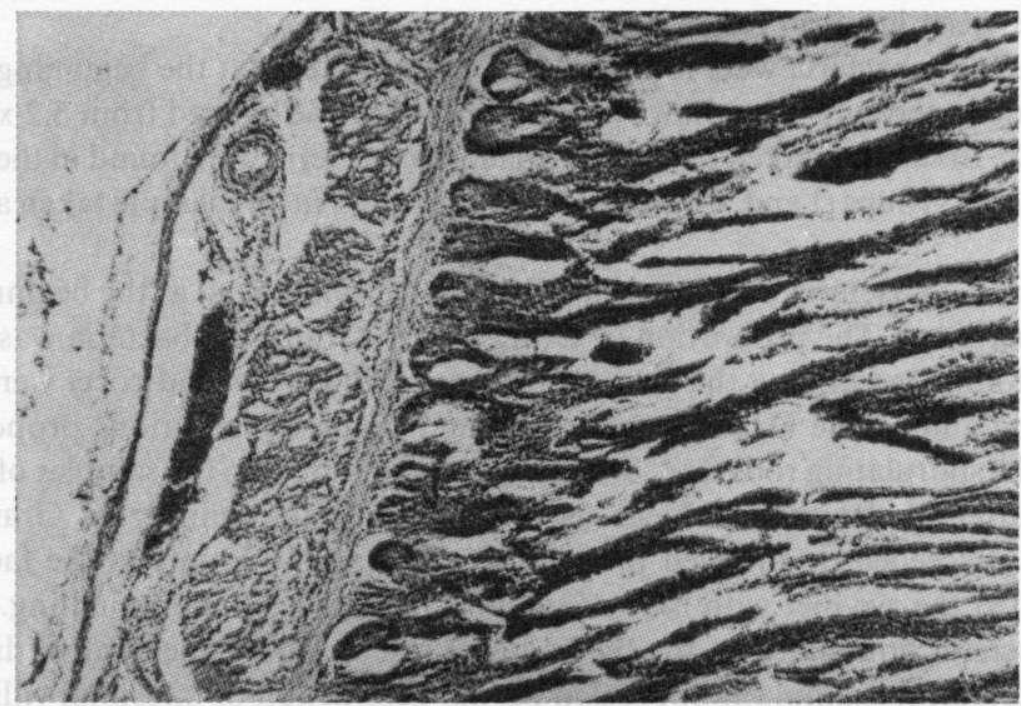

Fig. 1b. A cross - section of the intestinal wall after 3 weeks of feeding a rye diet with no additives: complety destroyed villi. The damage reaches the mucous membrane and muscle layer. The Brunner glands, muscle layer and serous membrane are normal

small intestine in all chicks fed the rye diets, regardless of the probiotic supplementation. The characteristic picture of cross-sections of intestinal cell walls is shown on Figs. la (duodenum) and $1 \mathrm{~b}$ (small intestine). After 3 weeks of feeding the diet containing $80 \%$ rye without any additives, the villi and intestinal glands were almost completely destroyed and the damage was seen even in the mucous and muscle layers. Villi structure was almost normal in the chicks receiving nisine (Figs. 2a and b), only in single villi apexes were lacking, in very few the protective epithelium was destroyed.

\section{DISCUSSION}

Feeding chicks on diets containing $80 \%$ rye (line 2256 ) with a high soluble dietary fibre content $\left(7 \%\right.$ ) with or without the addition of probiotics $\mathrm{P}_{1}$ and $\mathrm{P}_{2}$ led to damage and destruction of villi in the duodenum and small intestine. The numbers of anaerobic bacteria or coliforms did not increase faeces of chicks after 21 days of the experiment as compared with initial numbers at the start of the experiment. Wagner and Thomas (1978) showed, however, that feeding chicks rye diets stimulates the growth of anaerobes in the digestive tract which may unfavourably affect and damage the mucosa and villi. 


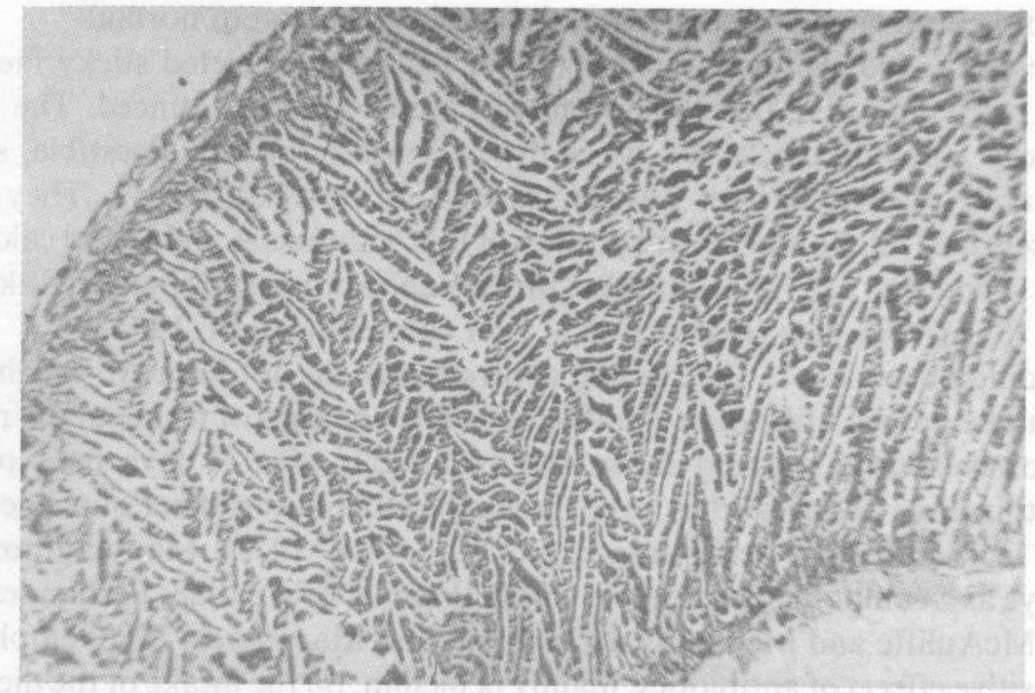

Fig. 2a. A cross - section of the duodenum wall after 3 weeks of feeding a rye diet with nisine. Single villi lacking apexes, very few have damaged epithelium most of the villi are normal

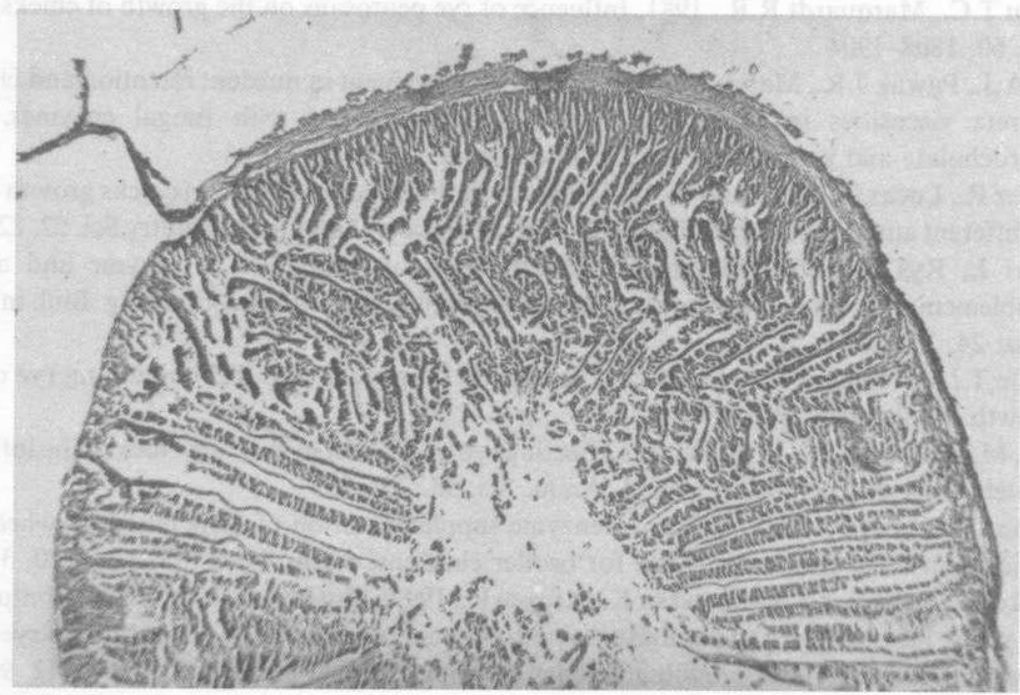

Fig 2 b. A cross - section of the intestinal wall after 3 weeks of feeding a rye diet with nisine. Most of villi are normal, single villi have damaged epithelium 
When nisine was included in the diet, the extent of degenerative changes of the villi and mucous membrane was smaller. Only in a few villi (Fig. 2a and b) apexes and epithelium were lacking, most of them however, were normal.

The chicks fed rye diets, irrespective of additives, excreted sticky faeces; in group receiving nisine these symptom was even more pronounced. The reason for sticky faeces in chicks fed rye is the presence of poorly digestible, soluble non-starch polysaccharides (Antoniou and Marquardt, 1981). They affect adversely feed intake and the absorption of fats, vitamins $A$ and $D$ and calcium in chicks (Fengler et al., 1988) as well as protein and amino acids in rats (Rakowska et al., 1992a) and pigs (Buraczewska, oral communication, 1992).

Adding probiotics to the rye and control diets did not improve weight gain, feed intake or feed utilization significantly. The addition of nisine to the rye diet did, however, stimulate feed intake and weight gain after 21 days, but worsened feed utilization. Many studies have shown the stimulating effect of nisine added to the feed on animal performance (cit. Woodbine, 1977). Many authors who used rye as a component of feed for chicks (Fengler et al., 1988; Fernandez et al., 1973; McAuliffe and McGinnis, 1971; Misir and Marquardt, 1978) emphasized the positive effects of antibiotics, mainly penicillin, on the intake of the diets with $50-60 \%$ of rye and the resulting improvement of chicks performance. The mode of action of the antibiotics is still not fully understood.

\section{REFERENCES}

Antoniou T.C., Marquardt R.R., 1981. Influence of rye pentosans on the growth of chicks. Poultry Sci. 60, 1898-1904

Fengler A.J., Pawlik J.R., Marguardt R.R., 1988. Improvement in nutrient retention and changes in excreta viscosities in chicks fed rye diets supplemented with fungal enzymes, sodium taurocholate and penicillin. Can. J. Anim. Sci. 68, 483-491

Fernandez R., Lucas E., McGinnis J., 1973. Influence of diet composition on chicks growth response to different antibiotics, food additives and combination of additives. Poultry Sci. 52, 2299-2305

Koreleski J., Ryś R., 1985. Preliminary investigation on the effect of enzyme and antibiotic supplementation on the feeding value of rye containing diets in broiler feeding. Biul. inf. Przem. Pasz. 24, 13-20

McAuliffe T., McGinnis J., 1971. Effect of antibiotic supplements to diet containing rye on chicks growth. Poultry Sci. 50, 1130-1134

Misir R., Marquardt R.R., 1978. Factors affecting rye utilization in growing chicks. The influence of protein level and penicillin. Can. J. Anim. Sci. 58, 703-715

Pettersson D., Aman P., 1988. Effects of enzyme supplementation of diets based on wheat, rye or triticale on their productive value for broiler chickens. Anim. Feed Sci. Tech. 20, 313-324

Rakowska M., Raczyńska-Bojanowska K., Kupiec R., 1992a. Studies on antinutritive compounds of rye grain. Part V. Effect of pentosanase pretreatment, sonication and extrusion of rye grain on protein digestibility and growth efficiency in chicks. Pol. J. Food Nutr. Sci. 1/42, 95-102

Rakowska M., Kupiec R., Rybka K., 1992b. Studies on the antinutritive compounds in rye. Part VI. Effect of dietary fibre fractions on protein digestibility in rats. Pol. J. Food Nutr. Sci. 1/42, 103-107 
Wagner D.D., Thomas O.P., 1978. Influence of diets containing rye or pectin on the intestinal flora in chicks. Poultry Sci. 57, 971-975

Woodbine M., 1977. Antibiotics and antibiosis in agriculture. Butterworths, London, Boston

\section{STRESZCZENIE}

Wpływ żyta, probiotyków oraz nizyny na mikroflorę odchodów i obraz histologiczny jelita cienkiego kurcząt

Zastosowanie diety zawierającej $80 \%$ ziarna żyta, o bardzo wysokim udziale $(7 \%)$ rozpuszczalnej frakcji włókna pokarmowego w żywieniu kurcząt brojlerów w wieku od 4 do 25 dni spowodowało silne uszkodzenie kosmków jelitowych oraz śluzówki dwunastnicy i jelita cienkiego. Zmiany te stwierdzono również u kurcząt otrzymujących takie same diety, do których dodano probiotyki zawierające bakterie fermentacji mlekowej.

Dodatek do diety z żytem antybiotyku nizyny w ilości $2 \mathrm{~g} / \mathrm{kg}$ chronił kosmki jelitowe dwunastnicy i dalszych odcinków jelita cienkiego przed uszkodzeniem. Dodatek nizyny zwiększył spożycie diety żytniej i powodował nieznaczne zwiększenie przyrostów masy ciała kurcząt, bez poprawy wykorzystania paszy.

Diety z żytem, tak bez jak i z dodatkiem probiotyków oraz nizyny, nie powodowały zmian w ilości i rodzaju bakterii z grupy Coli, beztlenowców oraz bakterii Gram $(+)$ i Gram (-) w odchodach kurcząt po 10 i 21 dniach żywienia w porównaniu ze stanem wyjściowym. 